\title{
Writing Northeast: Nandita Haksar's Across the Chicken Neck
}

\author{
Rosy Chamling \\ Department of English, Sikkim University. Email: rosychamling@gamil.com
}

\begin{abstract}
Traditionally travel literature has been a genre known for boosting colonial expansionist projects and the construction of the European 'Other'. Travel writing as an imperialist discourse serving to connect with the ideological apparatus of the European nation-state has been explored in Mary Louise Pratt's Imperial Eyes: Travel Writing and Transculturalism (1992). But contemporary travel literature is more subject-oriented, focussing on both the place and the people therein and the politics involved in the formation of their identity. It assumes the form of a cultural critique, called the 'countertravel' writing. Countertravel writing, then, aims not to delight the readers in its presentation of the exotic 'Other' but rather serves to transport the complacent reader causing the "unmapping" of "mapped" worldviews. (Richard Phillip, 1997). Within this paradigm of the 'countertravel' narrative, my engagement with Nandita Haksar's Across the Chicken Neck: Travels in Northeast India (2013) will be to show how Haksar seeks to 'unmap' the Northeast by writing her experiences with the people and places of Northeast India. Travelling through the 'chicken neck' which is a narrow strip of land connecting the Northeast with the rest of India; this paper will show how the apparently homogeneous Northeast has a diversity of stories and histories to tell. Burdened with histories of secessionism and insurgencies, Haksar's exploration exposes how these histories are subsumed by the larger national narrative.
\end{abstract}

Keywords : Northeast, Countertravel Writing, History, Identity.

\section{Introduction}

Canonical travel writing has never been an innocent project. The history of travel literature reveals how the earliest travels were undertaken primarily as funded colonial projects and how these nationalist empire-building projects were invariably Europe-centred. The traveller would generally be an imperial narrator, narrating accounts of the hitherto unseen world through a typical white male gaze. The early traces of such travel accounts exoticizing the new world can be found in Montaigne's Essays (1958) and in the Journals (1989) of Columbus. This made early travel writing inescapably political as discussed by Edward Said in Orientalism (1978), a book which exposed travel writing as laying the foundation to legitimize the European imperialism resulting in the construction of the Orient as a western construct. Said further documents the hierarchy arising from the binary between the centre and the margin resulting from such journeys in his book Culture and Imperialism (1993). Several such works in this direction have been brought out since then; important one like Mary Louise Pratt's Imperial Eyes (1992) show travel writing's intimate connection with the ideological apparatus of the European nation-state. Thus the element of 'wonder' associated with the discovery of new land and strange people with stranger cultures fuelled the colonial travel writings of the $18^{\text {th }}$ and $19^{\text {th }}$ century. Barbara Korte has coined the term imperialist travelogue to refer to this travel literature's entanglement with imperialist discourse (2000: 92). These travel accounts were different from the other travel descriptions of disciplines like History, Geography, Anthropology, or Sociology because it went

(C) AesthetixMS 2020. This Open Access article is published under a Creative Commons Attribution Non-Commercial 4.o International License (http://creativecommons.org/licenses/by-nc/4.o/), which permits non-commercial re-use, distribution, and reproduction in any medium, provided the original work is properly cited. For citation use the DOI. For commercial re-use, please contact editor@rupkatha.com. 
far beyond the dry reportage of facts. Besides the element of 'wonder', the exploitative narratorial accounts of colonial travel writings were overtly political in nature. However, contemporary travel writing calls for a different mode of understanding, both of the travel as well as of the writing of these travels. Contemporary travel literature is more subject-oriented, focussing on both the place and the people therein and the politics involved in the formation of their identity. It assumes the form of a cultural critique, called the 'countertravel' writing.

'Countertravel' writing, then, aims not to delight the readers in its presentation of the exotic 'Other' or to boost national identity but rather serves to transport the complacent reader causing the "unmapping" of "mapped" worldviews. (Phillip 143). Countertravel writing then demands a cross-cultural engagement through minor texts, unheard voices, dominant histories and grand narratives. Neither funded by an external agency nor fuelled by any nation-building ambition, the counter-traveller embarks on an independent journey to fulfil a subjective urge of engaging in a cross-cultural critique of people, history and cultures. It is this potential for cultural critique that makes Nandita Haksar's Across the Chicken Neck: Travels in Northeast India (2013) a piece of 'countertravel' writing. Nandita Haksar is a human rights lawyer who embarks on a road journey to explore the North east India. After having represented the Northeast in several human rights violation cases, her travel accounts are not to delight the readers with the presentation of the exotic Northeast. As she herself makes clear in the blurb of her book, the journey has been undertaken with an aim to unearth the invisible histories of the Northeast.

\section{Writing Northeast: Across the Chicken Neck}

The Northeast with its history of political unrest, ethnic strife and insurgency has been the 'Other' in the political and cultural imaginings of the mainland Indians. The Northeast broadly refers to the eight Indian states spread across the Eastern Himalayas and the Brahmaputra valley of the Indo-Myanmar Frontier-- Arunachal Pradesh, Assam, Manipur, Meghalaya, Mizoram, Nagaland, Tripura and Sikkim. Nandita Haksar, along with her Naga husband Sebastian, travel through the Chicken Neck via Nepal into the Northeast. The Chicken Neck refers to the thin strip of land which connects the Northeast with the rest of India while touching China in the North, Myanmar in the East, Bangladesh in the South and Bhutan in the Northwest. No doubt this shared boundary spanning almost $4500 \mathrm{~km}$ is of high strategic importance defence-wise. Often clubbed as a single geographical unit, the Northeast is actually a diversely multi-ethnic society. The term "North-East" in India has evolved from the concept of the "North-Eastern Frontier" used by the British for administrative convenience. Commenting on the formation of the Northeast, U.A. Shimray has observed:

Sujit Choudhury (1999) pointed out that the Balkanization of Assam into autonomous units of Nagaland, Meghalaya and Mizoram was the initial impetus that contributed to the coinage of the new nomenclature, the 'north-east', which in the course of time incorporated Tripura, Manipur and Arunachal Pradesh. Initially the concept remained a geographical one; it was politically formalised in 1972 when the North East Council (NEC) was formed through a President of India order. Thus, over the years, this geographical entity, the social setting, economy, politics and aspirations of the ethnic groups of the region were bunched together into one unit. ("Socio-political unrest in the region called North-East India" 2004, p. 4637)

Nandita Haksar's travels across the Chicken Neck to the Northeast has been undertaken with the intention of revealing how the northeast is not a homogeneous entity as perceived by the 
mainland Indians. Examining its diverse socio-cultural setting and engaging with its peoples, Haksar draws our attention to the reality that most strife in the Northeast is a reaction to this homogenising tendency.

\section{The Politics of History and Identity}

With a heightened sense of social consciousness, countertravel writing seeks to fuse the travelogue with their preoccupations with history, identity and belonging. Driving through the Chicken Neck, the couple first climb uphill from the plains of Siliguri towards Sikkim, the youngest entrant among the North Eastern Council in 2003. Despite the capital town Gangtok being closed due to the Nepali festival period, she is able to catch up with a brief history of Sikkim. Haksar gives an account of the mythological origin of the state of Sikkim which can be traced to the establishment of the Namgyal Dynasty in the $17^{\text {th }}$ century. Phuntsog Namgyal, the great grandson of Guru Tashi was consecrated as the first king of Sikkim in 1642 with the title of 'Chogyal' meaning 'religious king'. Towards the end of the $18^{\text {th }}$ century, the British came to Sikkim with trade and political interests in their mind. On February 10, 1817, Sikkim signed a treaty with the East India Company and by 1861 Sikkim became a de facto protectorate of the British. The land of Sikkim primarily constituted of the ethnic tribes of the Lepchas and Bhutias after the signing of the "blood brotherhood' treaty in 1641. Haksar observes how the demographic structure of Sikkim changed with the advent of the Nepalese as the British brought with them Nepalese people to facilitate them in their construction projects of opening the doors to Tibet and Nepalese labourers to work in the tea estates of Darjeeling and Sikkim. When in 1947 the Britishers left India, Sikkim's status was left undecided. But due to the influence of the National freedom movement of India, Sikkim's political scenario too was affected by waves of democracy. The Chogyal wanted an arrangement for Sikkim different from the other princely states. The Indian Government signed a treaty in 1950 retaining Sikkim's status as a protectorate but to be governed by an Indian Dewan from Delhi. The last Chogyal, in his bid to retain power, lost the faith of the majority Nepali subjects. As the anti-Chogyal political parties were rising and with their help, the Central Government was able to wrest powers from him. Sikkim became the $\mathbf{2 2}^{\text {nd }}$ State of the Indian Union by the $38^{\text {th }}$ Amendment Act of the Indian constitution. The early rumblings of political discontentment demanding the removal of monarchy led to the dethroning of the last and the twelfth Chogyal Palden Thondup Namgyal. The establishment of democracy started from the 1970 and eventually Sikkim was annexed to the Indian Union on $16^{\text {th }}$ May, 1975. But what has caught the attention of Haksar is the gradual undermining of the indigenous community of Sikkim, namely the Lepchas and Bhutias. However, in reality Sikkim has a history of the three communities, namely Nepali, Bhutia and Lepcha, living in peaceful coexistence indicating Sikkim's assimilation with the democratic waves blowing across the sub- continent.

Nandita Haksar has often contemplated on how the feats of the indigenous tribesmen have been obliterated from public memory. While there are copious amount of writings recording the great expedition of Francis Younghusband to Tibet through this route with much fanfare, the journey of Kinthup Lepcha who had discovered the source of the mighty Brahmaputra River in the face of enormous personal hardship is unheard of by many. The story of Kinthup Lepcha was only a recent discovery because for the major part of his life, he eked out his living as an unobtrusive tailor in Darjeeling. Similar fate awaited the stories of indigenous peoples from the other parts of Northeast. The next destination being Dhubri in Assam, she is pleasantly surprised to find Sikhism in Eastern India when she hears of the encounter of Netai Dhubuni, a sorceress, with the Sikh Guru Teg Bahadur Sahib. There is also another account of 
Guru Nanak's visit to Dhubri in 1505. According to the Sikh accounts, Kamrup was governed by a woman called Nurshah, a sorcerer who tried her magic upon Guru Nanak only to be subdued and reformed. Haksar notices how the history of the Northeast are mired in stories of magic and sorcery, perhaps to give it an air of the other worldly .Perhaps no one would have again imagined that the place also had a few number of Muslim relics like the Rangamati Masjid which is the oldest mosque in Assam. One group of historians claim it to have been built by Mir Jumla, the famous general of Aurangazeb while another group claim that it was built by Sultan Hussain Shah who ruled Bengal around 1500. Another such relic was the Panch Pir Dargah which was established in 1662 on the banks of Brahmaputra. It is believed that Dhubri got its name from Dhubuni or washerwoman (the same woman who tried her sorcery on the Sikh Guru ) but according to the Bodos, the word Dhubri is associated with a Bodo name for a special grass 'dubra' and the story of the washerwoman is just a myth. Haksar informs us that such counter myths were invented in the later period by the Brahmins to appropriate the earlier tribal religion and tradition. Interestingly, Dhubri also had remnants of Buddhism, although many staunch historians like B.K.Barua, R.C.Majumdar and N.K.Bhattasali claim that Kamrup has always been a Hindu preserve area, although there are historical records of the Chinese monk Xuanzang visiting India in the $7^{\text {th }}$ Century A.D.

Nandita Haksar finds it hard to believe that so little attention has been paid to examples of solidarity between different religions of the past. Unfortunately, the present is a witness to inter-religious conflict whereby the rule of the majority has led to the gradual erasure of local history and religion. The Northeast is a glaring example of one such place which bears rampant Hinduization of local cultures. The narrator points out how the old name for present Tezpur was Sonitpur, a part of the kingdom of Bali. Tezpur, the city of blood, was named after the Hindu mythical story of Lord Krishna. Similarly, in Assam Sankardev had founded a religion called EkaSaran Hari-Nama Dharma or the Religion of Supreme Devotion and Surrender to One God. During his lifetime this religious faith included devotees from various tribes including the Garo, the Mishing, the Karbi, the Sudhra and even the Muslims. Several Satras had sprung up after his death in 1568 but the narrator tells us how all Satradhikars were only Brahmins. Unfortunately Muslims were not allowed to be a part of these Satras and even people belonging to the Mishing tribe who had been living in the island were not included in any of the Satras.

She also tells us how the early Ahom kings had maintained a culture similar to the tribesmen, but it was only after their conversion to Hinduism that they had started maintaining caste distinctions and social distancing with the hill tribes. In a similar vein Haksar talks of the origin of the Karbis of Assam whereby the process of sanskritization which proceeds apace everywhere in the Northeast has given rise to the myth that the Karbis were the descendents of Sugriv, Hanuman's brother. The Karbis are tribals scattered throughout Assam and Haksar mentions Semsonsing Ingti (1910-48) who had made an ardent effort to unite the Karbis by forming the Karbi Adorbar in 1946 to bring to light the social and political marginalization faced by this tribe. But unfortunately Semsonsing did not receive support from his own people because of his conversion to Christianity. The narrator further elaborates how this communal divide within the Karbis prevented them from joining Meghalaya because Meghalaya was basically a Chrisitian dominated state and how religious divides in the northeast took priority over tribal solidarity. A small but significant place like Sadiya too bears a history of Hinduization:

Sadiya was the capital of the Chutiya kingdom which is said to have been established sometime between the twelfth and the thirteenth centuries. Later kings of the Chutiya kingdom came under the influence of Hinduism and, subsequently, the myth was 
invented that the Chutiya kings descended from King Bhismak, who was Lord Krishna's father-in-law. The Ahom Buranjis have records of fierce battles which were fought between the Chutiyas and the Ahoms. (Haksar, 2013, p. 107).

Haksar ruefully adds how all symbols of Assamese nationalism seem to be connected with the Ahoms and exclude the histories of other tribal communities. The museum in Shillong named after the man who led the struggle for the state of Meghalaya has cultural artefacts only of the three main communities living in Meghalaya, namely the Khasi, the Garo and the Jaintia. There is no record of the lesser known tribes living in Meghalaya since decades like the Lahung, the Koch, and the Rabha. Here too there is a secessionist story of the Garos. Many young Garos have taken to armed resistance in support of their demand for a separate Garoland, including the entire Garo Hills in Meghalaya, most of Goalpara and part of Kamrup district of Assam. Similarly upon her visit to the Assam State Museum, Haksar is taken aback to see that the official record of Assamese history tells us how the Ahoms entered the Brahmaputra Valley from Burma in the early period of $13^{\text {th }}$ century A.D. and ruled up to 1826 . Here again there is no mention of the Bodo, the Mishmi or the Karbi, the three most populous tribes of Assam. These observations lead Haksar to note how such obliteration of minor histories and unjust representations in the political and cultural landscape has led to insurgent and secessionist movements in the Northeast.

Religion too has been a very contentious issue in the Northeast. Unfortunately under the influence of mainstream Hinduism and Christianity, the ethnic religious belief systems have been gradually eroded by the local tribesmen. Today the ethnic religion, culture and tradition have unfortunately been reduced to an exhibition to promote tourism. It was upon reaching Dimapur in Nagaland that we hear her reacting strongly against the voyeuristic mass culture during her visit to the Hornbill Festival celebrated every $1^{\text {st }}$ of December. She informs how in 2009, Chief Minister Neiphiu Rio and his cabinet had declared Nagaland as 'the land of festivals' to capitalize on the colourful culture of the various tribes of Nagaland:

What strikes a discordant note is that of all the hundreds of photographers and tourists, not a single one bothers to pause and speak to any of the dancers. No one seems to want to hear their stories, to share their concerns, or to understand their difficulty of keeping alive a culture which has lost much of its meaning under the onslaught of organized religion. I am also disgusted by how the officers of the Indian security forces are brought by their soldiers to have photographs taken with the Naga performers. This is unashamed voyeurism. (Haksar, 2013, p. 135)

With the incursion of Christianity in Nagaland, ethnic tribal cultures can only be presented for mass tourist consumption. Out of curiosity Haksar tries to find out if there is a correlation between Christianity and development. She raises some thought-provoking statements like: "Why is it that non-Christian areas of the Northeast are the most backward and poor? They contrast dramatically with the Christian-majority states where the indices of human development and literacy rate are much higher than the national average." (Haksar, 2013, p. 177). The incursion of Christianity in the Northeast is one of the major reasons for the gradual disintegration of tribal folk religion and customs. The American Baptist and the Welsh Presbyterians were the major Christian missions in the Northeast throughout the $19^{\text {th }}$ century. These missions played a major role in introducing the tribals to the Christian faith via education. The first missionary Alexander Lish of the Baptist Mission, Cherrapunji opened a school. These missions through their social amelioration functions were able to win the faith of the tribals; but at the same time the evangelical function of missions challenged the very fabric of the indigenous society. The incursion of Christianity constructed an alternative societal structure for the tribals as a result of 
which many tribes disown their own indigenous religio-cultural system. For example the author notes how the Baptist Church allows the Garos to participate in their traditional drum festival as long as they do not involve themselves in the rites and rituals but, in the Khasi Hills, the Presbyterian Church forbids the Khasis from participating in any of the traditional festivals. Initially movements like the Seng Khasi, a movement which aimed at promoting, preserving and propagating of the old Khasi religion, Ka Niam Khasi in 1899 in Shillong. The primary aim of the Seng Khasi movement was to prevent the old Khasi belief from being destroyed by the Christian missionaries. However, the author notes how the movement lost its credibility and is believed to be close to the RSS wing. There is also evidence of resistance by the Jaintias against the Christian missionaries who had first come in 1842 to preach their new religion. Interestingly, the author notes how the Jaintia culture was once very similar to the Khasis but it was due to the influence of Brahmanism that that they had begun to fashion a Hindu identity for themselves. Similarly there is evidence of Manipur being Hinduized. Before the arrival of Hinduism, the Meitei people used to call their kingdom Kangleipak, Poireipak and Meitrapak. It was after Hinduism that the name of the kingdom was changed to Manipur. These Northeastern tribes are unfortunately caught between the Brahmanical values and the Christian Mission. The local tribal ethno-religious practices are being replaced either by the evangelical mission of Christianity or engulfed by the majoritarian religious practice of the Hindus.

Haksar's travel account is factual history and ethnography interspersed abundantly with her observations arising out of her personal engagement with these peoples and their history. Her first person narrative gives rise to an acutely self conscious literary mode leading many to question the neutrality of her narrative. However, her experiential mode of narration is best suited here to express the dialectic between what one has heard of them and what one sees and experiences. A countertravel narrative cannot help but be a very self-conscious art. In this respect, Paul Fussell's distinction between the explorer, the traveller and the tourist would be an interesting comparative positions: "All three", he says, "make journeys, but the explorer seeks the undiscovered, the traveller that which has been discovered by the mind working in history, the tourist that which has been discovered by entrepreneurship and prepared for him by the arts of mass publicity" (Fussell, 1980, p. 390). It is the counter-traveller who sets out to get inside the history of people and places to record through a very self-conscious craft.

\section{Conclusion}

If conventional travel texts have followed definite discursive strategies, a 'countertravel' text treads a more conscious approach because it is a journey into a seldom visited uncomfortable terrain. Analyzing women's travel writings, Sara Mills in her classic study "Discourse of Difference" (1991) has identified a set of gender restrictions on women and the power politics involved through the absences and denials of women in travel literature. A woman making a foray into a man's domain can equally be an uncomfortable journey, although there are travel accounts of women, either in accompaniment with other women or at times accompanied by a 'native' male companion. The gender bias in travel and travelling experience is implied through the use of terms like 'penetrated', 'husbanded', 'virgin land' which are ubiquitous in colonial travel narratives (Bassnett, 2002, p. 231). Therefore women who dared to leave the comfort and safety of the domestic space was considered as either 'exceptional' or 'masculine', but the presentation of women who attain things as exceptional was actually a tendency to downplay the achievements of women (Bassnett, 2002,p. 228). Women travel writers have an important role to play as countertravel narrators, choosing to fashion a new textual identity for themselves by freeing 
themselves from the colonizing forces of gender. Nandita Haksar's travel companion Sebastian is a native of the Northeast and besides his genial nature nothing much is revealed of him. Sebastian's experiences as a member of the Tangsa tribe, a tribe which is not recognized as a Naga tribe, is a specimen of not just the inter-ethnic and even intra-ethnic divide in the Northeast. The Nationalist Socialist Council of Nagaland (Isak-Muivah) recognizes only Protestantism as the religion of the Nagas; it does not even recognize the traditional Naga religion. Besides which the Northeast society being patriarchal and even the matrilineal Khasi society gradually assuming a patriarchal overtone, Haksar experiences discomfiture on issues surrounding her childless status. A society that celebrates fertility and the strength of a community depending on the number of children a woman bore, isolated her from them. Her child-free status and non-conversion to Christianity certainly become uncomfortable issues. Ruminating on the idea of home and identity, Haksar laments her own liminal position within the pan-Indian narrative:

Somewhere, deep in my subconscious, I feel that as an Indian I have been complicit in the injustice meted out to the peoples of the Northeast. Perhaps I even envy them because they have a homeland-- or at least they imagine they have one-- and I have none, except the Indian of my imagining. (2013, p. 157)

This idea of 'home' as a central trope has led to strong ideological construction of identity in the Northeast, a region which was already simmering with immigration problem, drug trafficking, ethnic turmoil, and insurgency history. Perhaps there is no household in the Northeast who has not suffered from this strife in one way or the other. The ethnically diverse Northeast has witnessed a series of secessionist movements, almost all of these claiming either a separate statehood or separation from the mainland India:

Manipur has the largest number of armed insurgent groups among all the Indian states in India: The Meitei groups challenge the legal and political validity of the merger between India and the Manipuri maharaja, Bodh Chandra Singh, by which the kingdom of Manipur was incorporated into the Indian Union. The Naga armed groups want the unification of the four Naga-inhabited districts of Manipur and the Naga-inhabited districts of Arunachal Pradesh and Assam with Nagaland. The Zomi groups demand a Zomi homeland which will require the Churachandpur district of Manipur to be subsumed within Mizoram and then united with the Zomi-inhabited areas of Myanmar. The Manipuri Muslims dream of an Islamic state. (Haksar, 2013, p. 157).

The imposition of the draconian Armed Forces Special Powers Act (AFSPA) has caused serious violation of human rights in the Northeast. The Meitei women are known for their protests called the 'meira painas' the torch bearers of society and by telling us a story of the brave Irom Chanu Sharmila who had been on hunger strike for more than a decade against the draconian AFSPA, Nandita Haksar shows how women have played an active role in resistance. The ethnic policy till recently has been based on demographic domination like the imposition of dominant language leading to xenophobic fear among the hill tribes. One of the major reasons could be underdevelopment of the region as most centrally funded development benefits seldom percolate to the grass root level. Efforts should also be made to check the lop-sided development of the region, some areas like the Brahmaputra valley being slightly more developed than the others. She also seems to be deeply perturbed by the gradual loss of ethnic indigenous history and identity due to the overpowering wave of larger Hindu culture. Caught between the crosscurrents of Brahmanism and Christianity, the Northeast is embroiled in an identity crisis. The Chicken Neck proves a vital zone for contact between the Northeast and the bordering foreign nations like China in the North, Myanmar in the East, Bangladesh in the South, and Bhutan in the North- 
West. It is thus imperative that the policy makers in Delhi understand the sensitivity of the area by implementing the all inclusive Act-East policy with caution. Haksar concludes,

Of course there are differences and conflicts of interests, but the people are ultimately united by the shared resistance to incorporation into the Sanskrit-speaking, caste-based society of the Aryans. The Indian-State, on the one hand, tries to promote the idea of the Northeast as a single entity for economic as well as political purposes. On the other, within the Northeast, it follows a vicious divide-and-rule policy which has caused widespread death and destruction. In the end, oppression has served to unite the people and has given them a sense of common identity. (Haksar, 2013, p. 139)

At one point she notes how the overarching idea of Assamese nationalism has bound the Ahoms together, but during the terror filled dark days of 1990s, the Operation Bajrang and Operation Rhino united all Assamese. At the end of her journey she contemplates on what links the Northeast have with mainland India. Besides the most obvious reason being the process of sanskritization and Hinduism, but at the same time she has also observed how the people of the Northeast are reclaiming their past and de-sanskritizing themselves. By bringing forth their indigenous culture and history, the Northeast is gradually seeking self determination which needs to be understood in a holistic manner. It is the chicken neck which binds the north east with the rest of India, and hence political solidarity and acceptance of cultural differences can go a long way in bringing peace to the much maligned region.

\section{References}

Bassnett, S. (2002). "Travel Writing and Gender". The Cambridge Companion to Travel Writing, Eds. Peter Hulme and Tim Youngs. Cambridge University Press.

Choudhury, S. (1999). “The North-East: A Concept Re-examined”. Dynamics of Identity and Intergroup Relations in North-East, ed. Kailash Aggarwal. Shimla, Indian Institute of Advanced Study.

Fussell, P. (1980). Abroad: British Travelling Between the Wars. Oxford University Press.

Haksar, N. (2013). Across the Chicken Neck: Travels in Northeast India. Rupa Publications.

Korte, B.(200o). English Travel Writing from Pilgrimage to Postcolonial Explorations. Macmillan.

Mills, S. (1991). Discourse of Difference: An Analysis of Women's Travel Writing and Colonialism. Routledge.

Phillips, R. (1997). Mapping Men and Empire: A Geography of Adventure. Routledge.

Pratt, M.L. (1992). Imperial Eyes: Travel Writing and Transculturation. Routledge.

Said, E. (1993) Culture and Imperialism. Vintage Books.

-----. (1979). Orientalism. Vintage Books.

Shimray, U.A. (2004). "Socio-Political Unrest in the Region”. Economic and Political Weekly. Vol. 39, No. 42. Oct 16-22, 2004. p. 4637.

Ury, J.(1990), The Tourist Gaze: Leisure and Travel in Contemporary Societies. Sage Publications. 